\title{
Hydrobiologia
}

\section{Pilot acoustic tracking study on adult spiny lobster (Palinurus mauritanicus) and spider crab (Maja squinado) within an artificial reef \\ --Manuscript Draft--}

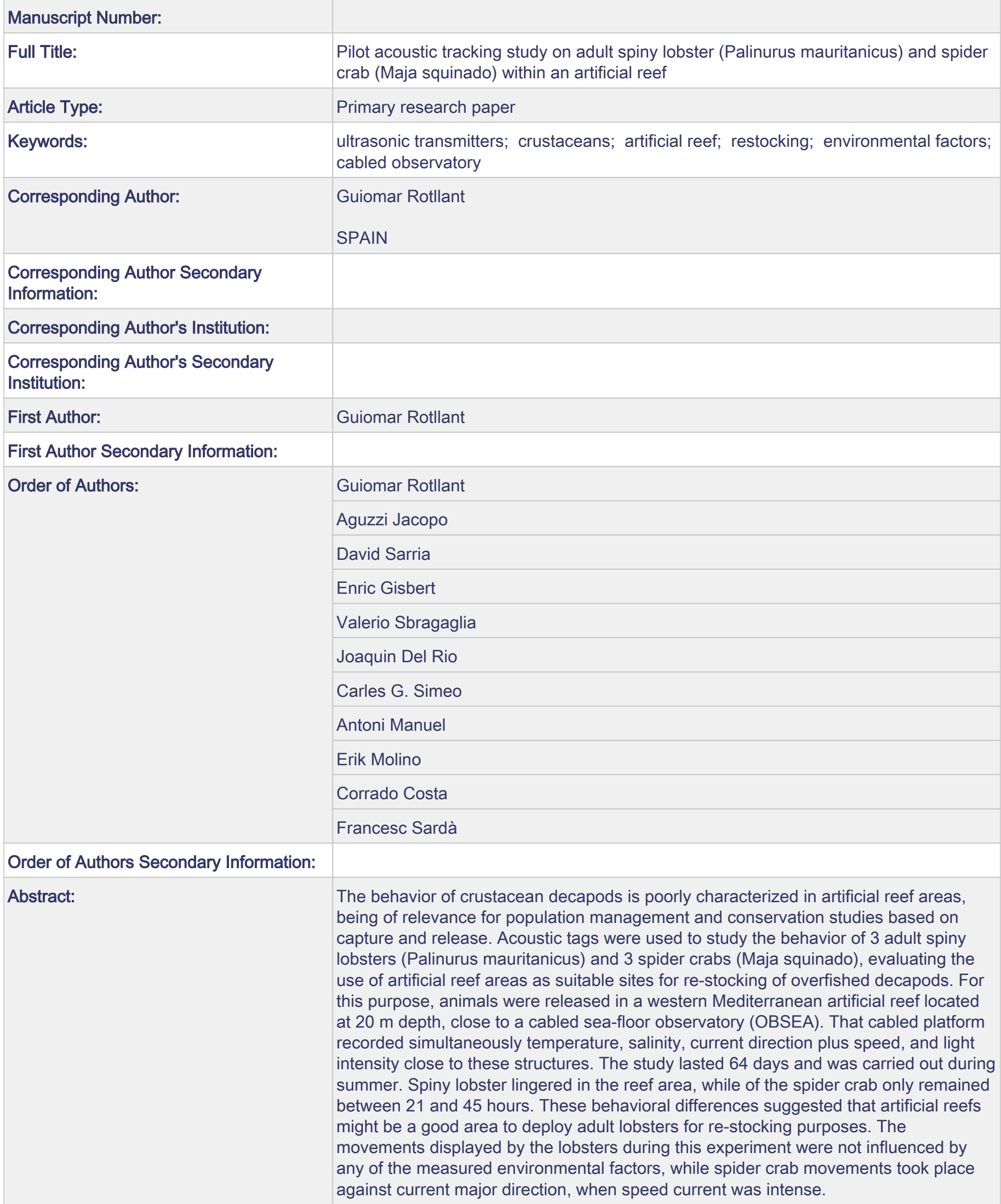




\section{Suggested Reviewers:}

Anette Ungfors

Anette.Ungfors@tmbl.gu.se

She have previous expèrience in tagging and re-stocking crabs

Antony Jensen

a.jensen@noc.soton.ac.uk

He have used artificial reefs to re-stock lobsters

Silvia Revenga

srevenga@mapa.es

She is working in the Spanish Ministry of Fisheries and she is in charge of artificial reef structures 
1 Research article to be submitted to Hydrobiologia

2

3

4 Pilot acoustic tracking study on adult spiny lobster (Palinurus

5 mauritanicus) and spider crab (Maja squinado) within an artificial reef

6

7

8 Guiomar Rotllant · Jacopo Aguzzi • David Sarria $\cdot$ Enric Gisbert $\cdot$ Valerio

9 Sbragaglia · Joaquín Del Río • Carles G. Simeó • Antoni Mànuel • Erik Molino •

10 Corrado Costa $\cdot$ Francisco Sardà

G. Rotllant $(\bowtie) \cdot$ J. Aguzzi $\cdot$ V. Sbragaglia $\cdot$ F. Sardà

13

Institut de Ciències del Mar (ICM-CSIC), Passeig Marítim de la Barceloneta 37-49

E-08003 Barcelona, Spain.

Tel.: (34) 932309500

Fax.: (34) 932309555

17 E-mail: guio@icm.csic.es

18

D. Sarria · J. Del Río · E. Molino · C.G. Simeó· A. Mànuel

Technological Development Centre for Remote Acquisition and Data Processing Systems (SARTI), Electronics Department, Universitat Politécnica de Catalunya (UPC), Rambla de l'Exposició 24,

E-08800 Vilanova i la Geltrú (Barcelona), Spain

E. Gisbert · C.G. Simeó

Unitat Operativa de Cultius Experimentals, IRTA

Carretera del Poblenou km 5.5, Sant Carles de la Ràpita

E-43540 Tarragona, Spain

C. Costa

Consiglio per la Ricerca e la sperimentazione in Agricoltura (Unità di ricerca per l'ingegneria agraria), Via della Pascolare, 16, I-00015 Monterotondo Scalo-Rome, Italy

J. Aguzzi · V. Sbragaglia · F. Sardà · D. Sarria · J. Del Río · E. Molino · A. Mànuel Associated Unit Tecnoterra 
39 Abstract The behavior of crustacean decapods is poorly characterized in artificial reef areas, being of relevance for population management and conservation studies based on capture and release. Acoustic tags were used to study the behavior of 3 adult spiny lobsters (Palinurus mauritanicus) and 3 spider crabs (Maja squinado), evaluating the use of artificial reef areas as suitable sites for re-stocking of overfished decapods. For this purpose, animals were released in a western Mediterranean artificial reef located at $20 \mathrm{~m}$ depth, close to a cabled sea-floor observatory (OBSEA). That cabled platform recorded simultaneously temperature, salinity, current direction plus speed, and light intensity close to these structures. The study lasted 64 days and was carried out during summer. Spiny lobster lingered in the reef area, while of the spider crab only remained between 21 and 45 hours. These behavioral differences suggested that artificial reefs might be a good area to deploy adult lobsters for re-stocking purposes. The movements displayed by the lobsters during this experiment were not influenced by any of the measured environmental factors, while spider crab movements took place against current major direction, when speed current was intense.

54

55

56 Key words: ultrasonic transmitters; crustaceans; artificial reef; restocking; environmental factors; cabled observatory 
60

In the western Mediterranean, lobsters and crabs stocks are threatened due to their past and present severe overfishing (Sardà \& Martin, 1986). For example, in the Western Mediterranean Catalan official landings of the last 10 years show how captures of benthic crustacean have significantly decreased of a $5 \%\left(\mathrm{p}<0.0013^{* *} ; \mathrm{R}^{2}=0.6227\right)$. These crustaceans are especially vulnerable because of their low mobility or ability to escape from divers and/or gear devices, and also by its high mortality in the early stages of development (Abad, 2003; Goñi \& Latrouite, 2005; Stevcic, 1967, 1977). The restocking in sensitive sites is a critical tool to preserve biodiversity, living resources, and for ecosystem conservation and can also be used as an effective tool for fisheries management (Bell et al., 2006). However, restocking is not an easy task and it would be desirable any essential knowledge on the behavior of individuals in relation to their movement patterns and in situ permanence within a specific area.

To our best knowledge no telemetric studies have been performed on the spiny lobster Palinurus mauritanicus Gruvel, 1911 and the spider crab Maja squinado (Herbst, 1788), although some data on the biology of these species is available (Bussani \& Zuder, 1977; Diop \& Kojemiakine, 1990; Durán et al., 2012; Goñi \& Latrouite, 2005; Guerao et al., 2008; Guerao \& Rotllant, 2010; Hunter, 1999; Rotllant et al., 2014; Stevcic, 1967, 1968, 1973, 1977). In contrast, the biology and behavior of other species within the same genus were approached by telemetry in Southern Europe, such as: Palinurus elephas (Fabricius, 1787) (Giacalone et al., 2006; Hunter, 1999) and Maja brachydactyla Balss, 1922 (Freire, 1999; Gonzalez-Gurriaran \& Freire, 1994; GonzalezGurriaran et al., 2002; Hines et al., 1995). Although some studies were initially referred to M. squinado they corresponded to M. brachydactyla, since animals were captured in 
83 the Atlantic and only recently populations has been ascribed to a different species

84 (Guerao et al., 2011; Sotelo et al., 2009). Previous studies for P. elephas showed a shelter-life habit (Giacalone et al. 2006; Goñi \& Latrouite, 2005) and short range displacements (i.e. > $5 \mathrm{~km}$ ), although

87 winter offshore migration was suggested by Hunter (1999). Herrnkind (1980) 88 conversely, defined three spatial categories of movement in spiny lobster: (1) homing 89 (the ability for a lobster to return to a specific shelter after foraging), (2) nomadic 90 (undirected, long range displacements away from current shelters), and (3) migratory 91 (vertical or horizontal seasonal displacements in and away from current shelters). 92 Although the variations of temperature, salinity, photoperiod, light levels, oxygen, and 93 so on, may be coincident with lobster movements, Herrnkind (1980) failed in 94 identifying key eliciting stimuli. Recently, Bertelsen (2013) probed that the percentage 95 of lunar illumination triggers the movement of large males of Panulirus argus 96 (Latraille, 1802). The spiny lobster Panulirus cygnus George, 1962 seems to displace 97 according to current directions (Jernakoff \& Phillips (1988). Counter-current migration 98 apparently favour larval dispersal in Palinurus delagoae Barnard, 1926 (Groeneveld, 99 2002), Palinurus gilchristi Stebbing, 1900 (Groeneveld \& Branch, 2002) and Jasus 100 verreauxi (H. Milne-Edwards, 1851) (Booth, 1997). In a later mark-recapture study the 101 Rock lobster, Jasus edwardsii (Hutton, 1875) chiefly remained within 5 km (Linnane \& 102 Dimmlich, 2005). MacArthur et al. (2008) using acoustic telemetry also observed that 103 sub-adults of the lobster P. cygnus in the absence of fishing pressure do not displace. $J$. 104 edwardsii adults move seasonally to close deep waters however no correlation was 105 found between temperature, wave surge or photoperiod and their movements 106 (MacDiarmid, 1991). In the Mediterranean, the slipper lobsters Scyllarides latus 107 (Latraille, 1802) migrate into deeper water as the sea temperature rises in summer, but 
tagged individuals were seen to return to the reef over a 3 year period (Spanier et al., 1988). In the South African coast, it has been demonstrated by acoustic tracking that males of Jasus lalandii (H. Milne-Edwards, 1851) displayed classical nomadic behaviour (Atkinson et al., 2005).

Spider crabs also present seasonal migrations. Stevcic (1973) suggested a reproductive migration pattern since captures of $M$. squinado adult males in the Adriatic Sea reach a maximum in April, while females present it in May. In a mark-recapture experiment Bussani \& Zuder (1977) released mainly females from the Yugoslavian coast to Trieste and observed that at least $40 \%$ of the animals remained in the release area during 120 days, nevertheless in the following two years $3 \%$ of the released crabs were found far from the release area. In the sibling species $M$. brachydactyla markrecapture studies demonstrated that crabs moved as far as $200 \mathrm{~km}$ (Camus, 1983; Latrouite \& Le foll, 1989; Le Foll, 1993). Later, an ultrasonic telemetry study showed that adult crabs migrated in autumn to deep-water when temperature and salinity in shallow areas dropped while juveniles remained in coastal areas (Gonzalez-Gurriaran \& Freire, 1994). Other behavioural studies with acoustic tagging that blue crab Callinectes sapidus M.J. Ratthbun, 1896 males move to deeper waters to avoid ice in winter while female migrate long distances to the lower bay to incubate the eggs (Davis et al., 2005b; Hines et al., 1995). The portunids crabs Arenaeus crirabius (Lamarck, 1818) and Callinectes ornatus Ordway 1863 have erratic spurts and showed movement away from their area of release of 18 and 4 km, respectively (Guerra-Castro et al., 2007). Cancer pagurus Linnaeus, 1758 males were captured 1 to $8 \mathrm{~km}$ from their point of release in a 7 years study whereas females moved longer distances, up to $21 \mathrm{~km}$, in autumn with a net southerly direction (Ungfors et al., 2007). In the same study, the acoustic tracking of males showed both directed and irregular movements over thousands meters. Acoustic 
Say, 1817 in an estuarine mussel aquaculture site in Canada. Resident males migrated upstream in winter and returned to the estuary in spring while few translocated crabs returned to the estuary (Comeau et al., 2012). Scylla serrata (Estampador, 1949) is a mangrove resident crab; mark-recapture experiments demonstrated that $93 \%$ of juveniles recovered remain in the release area, adult females moved longer distances than males, and only mature females migrated into the sea to spawn (Hill, 1975; Hyland et al., 1984; Le Vay et al., 2007). Juveniles of the blue also stay in the release area (Davis et al., 2004; Davis et al., 2005b).

Artificial reefs appear to be a tool of coastal management that helps to share coastal zone resources among users (Jensen et al., 2000; Nonaka et al., 2000). These structures have been deployed in many muddy coastal areas in Europe under fishing impact with two main goals: avoid trawling and to concentrate biomasses; thus, increasing fishing efficiency, but may also provide new habitat for juveniles collected from elsewhere in smaller artificial habitats (Eggleston et al., 1990). Artificial reefs were implemented in 1992 off the Vilanova i la Geltrú (the Spanish western Mediterranean), where trawling was already prohibited (Revenga et al., 2000), in an area that today hosts the cabled coastal Seafloor Observatory (OBSEA; Aguzzi et al., 2011). That platform is used for the continuous multiparametric ecosystem survey hosting instruments for long-term monitoring of different oceanographic parameters. The coupling of that platform with the existing artificial reefs make the OBSEA site a suitable zone for interdisciplinary studies on individual and population behaviour (Aguzzi et al., 2013; Condal et al., 2013). spiny lobster and the spider crab in artificial reef areas by releasing animals where the 
multiparametric OBSEA platform is deployed. Acoustic detections on the positioning of animals were compared with concomitant measurements of water mass properties as provided by the OBSEA in a first attempt to evaluate which factors may influence individual behaviour, being hence of relevance of tagging-release studies at the base of restocking policies .

\section{Materials and methods}

Animals' origin and artificial reef location and description

Adults $P$. mauritanicus ( 3 males; $72 \pm 2 \mathrm{~mm}$ carapace length, CL) were caught by a trawling fishing boat from the Vilanova i la Geltrú harbor (Barcelona, Spain; Fig. 1) and kept within a in $200 \mathrm{~L}$ tank connected to a recirculation unit providing constant conditions of salinity $(36 \%)$ and temperature $\left(18^{\circ} \mathrm{C}\right)$ for $24 \mathrm{~h}$ without feeding until the next-day release. Adult $M$. squinado (3 males; $155 \pm 10 \mathrm{~mm} \mathrm{CL)} \mathrm{were} \mathrm{captured} \mathrm{off} \mathrm{the}$ North of Corsica (France) and transported to the facilities of the IRTA (Sant Carles de la Ràpita, Spain), where they were hosted in 2000 L tanks with recirculating water system (IRTAmar@TM) during three months at condition equals to those of Palinurus. Spider crabs were transported to Vilanova i la Geltrú the same day of releasing. Animals were fed with mussels and fresh crab (Liocarcinus depurator Stimpson, 1871 and Macropipus tuberculatus Prestandrea, 1833) until their liberation in the artificial reefs. The day before realizing, animals were unfed.

The artificial reef area is composed by a mixture of 20 protection and production modules located $4 \mathrm{~km}$ off of Vilanova i la Gertru at a depth of $20 \mathrm{~m}$. In particularly, the 4 production modules close to the coastal Seafloor Observatory (OBSEA; 
www.obsea.es) were used for the study (Fig. 2). Each production module is formed by a big $(1 \times 1 \times 2 \mathrm{~m})$ and heavy $(5 \mathrm{t})$ cement structure that stand proud of the seabed and have holes and sheltered spaces in them to encourage epibiotic colonization and promote fish recruitment (Revenga et al., 2000). Summer period (July to September) was chosen for the experiment since anticyclonic conditions ensured the maintenance and monitoring of equipment with reduced risks of storms.

Tagging methodology

VEMCO Ltd (Halifax, Canada) ultrasonic telemetry equipment was used to monitor the movements of animals. Four hydrophones $(\mathrm{H})$ (model: VR2W Coded Acoustic Receiver kept in the tank with the magnet attached to the transmitter as showed for the transmitter 
out and the signal and recording started as showed for the transmitter glue to the cephalothorax of the lobster hanging in the artificial reef module.

Animals were released inside the artificial reefs by SCUBA divers- on the $18^{\text {th }}$ of July 2011. Only adult males (carapace length of $72 \pm 2$ and $155 \pm 10 \mathrm{~mm}$ for lobsters and crabs, respectively) were chosen for this study, to avoid potential interferences with reproductive cycle. One lobster and one spider crab were released in each artificial reef (AR1, AR2 and AR3). Experiment ended the $20^{\text {th }}$ of September 2011 when hydrophones were recovered.

Transmitters were programmed to emit data every 30 seconds in order to extend the battery life of the transmitter during the 64 days that lasted the study. All transmitters sent data in the same way, so if two or more transmitters were working together there might be some signal collisions or false detections. However, after each transmission, the transmitters waited a random time until the next transmission, greatly reducing potential false detections. If the transmitter was in the reception area of the hydrophone, the identification (ID) of the transmitter was stored along with a timestamp and the serial number of the hydrophone. Later, crossing the data between hydrophones allowed checking the range of transmitters or evaluating the interferences of the reef's walls.

\section{Behavioral data collection}

ID data were time-stamped and stored in the memory of each hydrophone. VUE software allowed the data downloading to tabulated files. The estimation of trajectories was performed analyzing the number of detections of each hydrophone per hour. When the animal left a sector covered by a certain hydrophone, displacing to the nearby one, the number of detections of the former decreased and increased in the latter. 

realized by each specimen), a reference value of zero activity is required. Activity indicates the animals' displacements per unit of time as indicated by pin detections within the hydrophone network. That network infrastructure is able to identify animal presence as far as $200 \mathrm{~m}$ of distance form acoustic detecting sources. Drops in detections at one source indicate the movement of the animal away from it. Thus, the implemented algorithm considered a maximum in activity when the number of detections was minimal (i.e. the animal was moving, hence leaving the zone and detections were scaled to percentages, and the activity between individuals and species could be compared.

Environmental data collection

The CTD - SeaBird SBE-37SMP- and ADPC - Nortek AWAC current profiler - are the instruments connected to the OBSEA infrastructure that provides the following environmental data: temperature, pressure, salinity, current speed and current direction.

247 These data were processed by LabVIEW all the variables were averaged per hours.

248 Light intensity data were gathered from an automatic meteorological station (http://www.meteo.cat/xema/AppJava/SeleccioPerComarca.do) part of the the Servei Meteorologic de Catalunya in $\mathrm{W} / \mathrm{m}^{2}$. The meteorological station is placed in Sant Pere de Ribes, $6 \mathrm{~km}$ away from OBSEA.

Statistical analysis

A Canonical Correlation Analysis (CCA) was performed on the dataset. CCA is a multivariate statistical model that facilitates the identification of interrelationships 
among sets of multiple dependent variables with single or multiple independent variables (Sherry \& Henson, 2005). In our case, the correlation between the mobility of each species (independent variable) and a set of independent variables was studied.

These set independent variables were: temperature $\left({ }^{\circ} \mathrm{C}\right)$, pressure (dBar), salinity (PSU), water current speed $(\mathrm{m} / \mathrm{s})$ and direction (degrees in relation to North), and light irradiance $\left(\mathrm{W} / \mathrm{m}^{2}\right)$.

\section{Results}

Spiny lobsters $(\mathrm{P})$ presented low activity patterns and mainly remained in the artificial reef area where they were released (Fig. 3a; Table 1). Movements were realized at any time of day-night cycle. The lobster released in the AR1 moved to the AR3 and its activity was lost on the $28^{\text {th }}$ of August 2011. The specimen released in the AR2 remained around this production module; however, recovery data was partially missing between July $28^{\text {th }}$ and August $31^{\text {th }}$. The lobster released in the AR3 moved around this module, but stopped moving after the $28^{\text {th }}$ of July. At the end of the study, when SCUBA divers visited the study area, they found that this specimen was dead.

All spider crabs (M), showed a higher activity profile than the lobsters, either at day or night. Spider crab activity was tracked for a maximum of $48 \mathrm{~h}$ when the signal of the transmitter was lost, because they were out of the area of reception of the hydrophones (Fig. 3b; Table 1). The spider crab released in the AR1 moved South to $\mathrm{H} 4$, then went back to North-East direction, turned to West and finally moved again to the South. The spider crab released in the AR2 went to the East after being released and then turned to the South. The spider crab released in the AR3 moved to the South and left the artificial reef area in that direction. 

spider crabs and the following environmental parameters: salinity and pressure;

282

although some animals presented significant differences that were not supported by other crabs or lobsters (Table 2). Temperature was positively correlated with movement of spider crabs, but no effect was observed in two lobsters while P3 presented a negative correlation (Table 2). Current speed and direction did not increase until $20 \mathrm{~h}$ after the animals were released. There was a trend, although not statistically significant, between the current speed and light intensity and the movement of the spider crab (M2) that presented the higher time of detection in the reef area. M3 moved first towards the North-West and when the speed of the current speed increased and its direction was from the North. Then M3 changed the direction of the movements towards the East. M2 also presented a correlation of its movement with the current speed, moving towards the South when the strongest current from North appeared. M1 moved first to the East, but then also exited the AR in the South direction (Table 2). As a general pattern when current speed was intense spider crabs moved against the current.

\section{Discussion}

Our pilot study suggests that the artificial reef areas might be good sites for stocking and conservation of adult Palinurus mauritanicus, but not for adults of Maja squinado, since our released males left their deployment areas in less than 48 -h. This behaviour was correlated with different changes in some tested environmental parameters.

The two released spiny lobsters remained in the same module where they were initially placed by the SCUBA divers and the third one moved from the AR1 to the AR3 (114 m). In J. lalandi and P. cygnus it was observed significantly greater movements in the first two days following tagging and release although nomadic movements were 
described for this species (Atkinson et al., 2005; MacArthur et al. 2008). In our study, the movement of $P$. mauritanicus ranges were limited, remaining most of the time inside the module confirming the sheltering life-habit observed in other areas (Latrouite et al., 1999). Tag-recapture studies conducted in the Atlantic Ocean and Mediterranean Sea with the closer spiny lobster species, $P$. elephas, indicated that adult movements are generally restricted ( $5 \mathrm{~km}$ in 8 years) and that they are primary active at night for foraging and reproduction (reviewed by Goñi \& Latrouite, 2005). In the Mediterranean, slipper lobsters migrate into deeper water as the sea temperature rises in summer, but tagged individuals were seen to return to the reef over a 3 year period (Spanier et al., 1988). In our study, no correlation with light or any other environmental factors was found in P. mauritanicus, while Bertelsen (2013) probed that the percentage of lunar illumination triggers the restricted movement of large males of P. argus. The site fidelity and the limited movements of palinurid lobsters directed fisheries management towards the use of marine reserves to protect lobster populations enhance $P$. elephas adult stock biomass in the Mediterranean (Goñi et al., 2001) and it is known that marine reserves are most effective in species of intermediate movements as $P$. elephas. Lobster and fish biomass export was observed in the vicinity of the reserve and extended as far as $2500 \mathrm{~m}$ (Goñi et al., 2008). The creation of spiny lobster

326 fishing grounds through the utilization of concrete blocks began in 1933 and it has been 327 proved that artificial reefs increased the yield of lobsters in Japan (Nonaka et al., 2000). Artificial reefs were also used to restock homarid lobster in United Kingdom (Jensen et al., 2000). The limited movements of $P$. mauritanicus observed in the present study and 
the restriction of fishing in the artificial reefs induced us to propose the use of the infrautilized artificial reefs in the Catalan coast for re-stocking this lobster species.

The spider crab presented higher activity compared to the spiny lobster and we were able to record their movements only between 21 and 45-h-post releasing. Their movements were correlated with current speed and direction, as well as light intensity, while no effect on their movement ranges was observed by changes in temperature and salinity. Current speed increased 20-h after the releasing of crabs, when the movement of individuals generally occurred against the water flow. Movements of the spider crabs preferentially occurred during the daylight phase and increased with increasing temperature. M. squinado migrate towards deeper zones in autumn and return to shallower and nursery areas in spring, where juveniles stay (Bussani \& Zuder, 1977; Stevcic, 1967, 1973) but mark-recapture studies cannot provide a detailed description of the adult movement nor of elicit environmental factors. $M$. brachydactyla presented a similar migration pattern (Gonzalez-Gurriaran \& Freire, 1994) and adults move out from Spanish Atlantic fjords 3-fold faster than juveniles and sub-adults, with a positive correlation with temperature, as we found here. Corgos et al. (2011) confirmed that movement, observing also that all crabs recaptured on deep bottoms showed clear directionality moving towards the North, while in autumn the main current is from the South. Differences in movements between juveniles and adults were also observed in the blue crab C. sapidus, only adults moved directional into the main stem of Chesapeake Bay with a speed more than twice those of juveniles (Hines et al., 1995). While M. brachydactyla and C. sapidus did no present different behavior in their movement patterns between sexes (Hines et al., 1995), females of $C$. pagurus migrated significant longer distances with a net southern direction and males stayed within the area of release with short movements also directional (Ungfors et al., 2007). A two 
month acoustic transmitter experiment realized by the former authors with nine crab males showed a varied individual pattern: some individuals stayed in the same area for weeks, whereas some made regular movements every day during the tracking period. Although the movements were correlated with temperature in M. squinado from the present study no correlations were observed with this environmental factor and other in another crab species (Guerra-Castro et al., 2007). In contrast to palinurid lobsters, crabs realized migrations as adults (present study, André et al., 2012; Hines et al., 1995; Ungofors et al., 2007) and present a short ontogenic development (cf. Guerao et al., 2008; Johnson et al., 2011, Ut et al., 2007). Over the last decade, this short development in comparison to spiny lobsters (Nonaka et al., 2000), allowed researcher technically and economically feasible hatchery production of juvenile crabs as the mud crab Scylla spp. (Lebata et al., 2009; Le Vay et al., 2008; Ut et al., 2007), the swimming crab Portunus trituberculatus (Miers, 1876) (Okamoto et al., 2004) and the blue crab $C$. sapidus (Davis et al., 2004, 2005a, b; Johnson et al., 2011) with a net increase in fisheries' yield. Therefore, re-stocking programs in crabs has been based in the release of juveniles instead of adults, although has stated by Lebata et al. (2009) there is a need for species and site-specific studies. During the three years re-stocking Spanish project REPES we developed hatchery technology to grow up larvae and juvenile of the spider crab M. squinado (Durán et al., 2012; Guerao et al., 2008; Guerao \& Rotllant, 2010; Rotllant et al., 2014) however we do not reach enough mass production to be able to release juveniles. As stated by Corgos et al. (2011), juveniles of the sibling species $M$. brachydactyla are nomadic and therefore we suggest that the realease of juveniles of $M$. squinado in the artifical reef could be a proper restocking technique in the Mediterranean for this species overfished and strictily protected (Abad, 2003; Anonymous 1999). 

tracking for adult male lobsters and crabs in a well dispersed reef environment. Our

piloting results suggest that male lobsters remain, for a short summer period, within the reef structures. This highlights the potential for lobster restocking of artificial reefs. suggest that the AR could be a potential releasing area for juveniles up to newly mature adults (1-3 months after terminal molt). Finally, current speed and direction, light and temperature were environmental factors triggering the movements of the spider crabs.

Current direction was the main factor for spider crab movements and the spider crab direction was against current when speed current was intense.

\section{Acknowledgements}

This work was supported by the Spanish Ministry of Economy and Competitiveness under the research project: "Redes de sensores submarinos acústicos aplicados al seguimiento de especies de interes comercial" (TRA2009_0294) to AM and to National Sea Harvest Advisory Board (JACUMAR) belonging to the Ministry of Agriculture, Food and Environment under the research project: "Propuestas y mejoras para el diseño y control de los planes de repoblación y evaluación del impacto de los escapes REPES" to GR. The authors would like to thank Glòria Macià and Esteban Hernández for their support as laboratory technicians at IRTA, Sant Carles de la Ràpita, and the

400 "Servei Meteorologic de Catalunya" for providing data from their automatic meteorological station. 


\section{References list}

403

404

405

406

407

408

409

410

411

412

413

414

415

416

417

418

419

420

421

422

423

Abad, R., 2003. Reserva marina y pesca en la isla de Alborán (España). In Moreno, D. \& A. Frías (eds) Actas de las I Jornadas sonre Reservas Marinas y I Reunión de la Red Iberoamericana de Reservas Marinas (RIRM) Ministerio de Agricultura, Pesca y Alimentación. Secretaría General Técnica, Cabo de Gata, Almería, Spain, 17-23 de septiembre de 2001, 47-54.

Aguzzi, J., A. Manuel, F. Condal, J. Guillen, M. Nogueras, J. del Rio, C. Costa, P. Menesatti, P. Puig, F. Sarda, D. Toma \& A. Palanques, 2011. The New Seafloor Observatory (OBSEA) for Remote and Long-Term Coastal Ecosystem Monitoring. Sensors 11(6):5850-5872 doi:10.3390/s110605850.

Aguzzi, J., V. Sbragaglia, G. Santamaría, J. Del Río, F. Sardà, M. Nogueras \& A. Manuel, 2013. Daily activity rhythms in temperate coastal fishes: insights from cabled observatory video monitoring. Marine Ecology Progress Series In press (DOI: 10.3354/meps10399).

Anonymous, 1999. Décret no 99-615 du 7 juillet 1999 portant publication des amendements aux annexes I, II III et IV de la convention relative à la conservation de la vie sauvage et du milieu naturel de l'Europe (ensemble quatre annexes) ouverte à la signature à Berne le 19 septembre 1979, adoptés à Strasbourg le 5 décembre 1997 JO No 164.

Atkinson, L.J., S. Mayfield \& A.C. Cockcroft, 2005. The potential for using acoustic tracking to monitor the movement of the West Coast rock lobster Jasus lalandii. African Journal of Marine Sciences 27(2): 401-408. 
Bell, J. D., D. M. Bartley, K. Lorenzen \& N. R. Loneragan, 2006. Restocking and stock enhancement of coastal fisheries: Potential, problems and progress. Fisheries Research 80(1):1-8 doi:10.1016/j.fishres.2006.03.008.

Bertelsen, R. D., 2013. Characterizing daily movements, nomadic movements, and reproductive migrations of Panulirus argus around the Western Sambo Ecological Reserve (Florida, USA) using acoustic telemetry. Fisheries Research 144:91-102 doi:http://dx.doi.org/10.1016/j.fishres.2012.12.008.

Bussani, M. \& A. M. Zuder, 1977. Immisione di Maia squinado (Herbst) fiel golfo di Trieste. Rep Mar Park Miramare Trieste, 6:25-28.

Camus, P., 1983. Resultats d'une operation de marquage d'araignee de mer (Maia squinado, Herbest) adult en baie d'Audierne (Bretagne Sud) ICES Shellfish Communication, CM. vol K: 29, 11.

Comeau, L. A., R. Sonier \& J. M. Hanson, 2012. Seasonal movements of Atlantic rock crab (Cancer irroratus Say) transplanted into a mussel aquaculture site. Aquacuaculture Research 43(4):509-517 doi:10.1111/j.13652109.2011.02856.x.

Condal, F., J. Aguzzi, F. Sardà, M. Nogueras, J. Cadena, C. Cosat, J. Del Río \& A. Mànuel, 2013. Seasonal rhythm in a Mediterranean coastal fish community as monitored by a cabled observatory. Marine Biology 159:2809-2817.

Corgos, A., C. Bernardez, P. Sampedro, P. Verisimo \& J. Freire, 2011. Spatial structure of the spider crab, Maja brachydactyla population: Evidence of metapopulation structure. Journal of Sea Research 66(1):9-19 doi:10.1016/j.seares.2011.04.011. 
Davis, J. L. D., A. C. Young-Williams, R. Aguilar, B. L. Carswell, M. R. Goodison, A. H. Hines, M. A. Kramer, Y. Zohar \& O. Zmora, 2004. Differences between Hatchery-Raised and Wild Blue Crabs: Implications for Stock Enhancement Potential. Transactions of the American Fisheries Society 133(1):1-14 doi:10.1577/T03-004.

Davis, J. L. D., A. C. Young-Williams, A. H. Hines \& O. Zmora, 2004b. Comparing two types of internal tags in juvenile blue crabs. Fishseries Research 67(3):265274 doi:10.1016/j.fishres.2003.11.005.

Davis, J. L. D., M. G. Eckert-Mills, A. C. Young-Williams, A. H. Hines \& Y. Zohar, 2005. Morphological conditioning of a hatchery-raised invertebrate, Callinectes sapidus, to improve field survivorship after release. Aquaculture 243(1-4):147158.

Diop, M. \& A. Kojemiakine, 1990. The pink lobster (Palinurus mauritanicus) of Mauritania: Biology, fishery and state of the stock. Bulletin scientifique du Centre National de Recherches Oceanographiques et des Peches (Mauritania) $21: 15-21$

Durán, J., E. Pastor, A. Grau \& J. M. Valencia, 2012. First results of embryonic development, spawning and larval rearing of the Mediterranean spider crab Maja squinado (Herbst 1788) under laboratory conditions, a candidate species for a restocking program. Aquaculture Research 43:1777-1786.

Eggleston, D. B., R. N. Lipscius, D. L. Miller \& L. Coba Letina, 1990. Shelter scaling regulates survival of juvenile Caribbean spiny lobster Panulirus argus. Marine Ecology Progress Series 62:79 88. 
470 Freire, J., González-Gurriarán, E., Bernárdez, C., 1999. Migratory patterns in the spider crab Maja squinado using telemetry and electronic tags. ICES CM 1999/AA $14: 1-11$

473 46(2):127-142.

Giacalone, V. M., G. D'Anna, C. Pipitone \& F. Badalamenti, 2006. Movements and residence time of spiny lobsters, Palinurus elephas released in a marine protected area: an investigation by ultrasonic telemetry. Journal of the Marine Biological Association of the United Kingdom 86(5):1101-1106 doi:10.1017/s002531540601407x.

Gonzalez-Gurriaran, E. \& J. Freire, 1994. Movement patterns and habitat utilization in the spider crab Maja squinado (Herbst) (Decapoda, Majidae) measured by ultrasonic telemetry. Journal of Experimental Marine Biology and Ecology 184(2):269-291 doi:10.1016/0022-0981(94)90009-4.

Gonzalez-Gurriaran, E., J. Freire \& C. Bernardez, 2002. Migratory patterns of female spider crabs Maja squinado detected using electronic tags and telemetry. Journal of Crustacean Biology 22(1):91-97 doi:10.1651/02780372(2002)022[0091:mpofsc]2.0.co;2.

Goñi, R. \& D. Latrouite, 2005. Review of the biology, ecology and fisheries of Palinurus spp. species of European waters: Palinurus elephas (Fabricius, 1787) and Palinurus mauritanicus (Gruvel, 1911). Cahiers de Biologie Marine 
Goñi, R., S. Adlerstein, D. Alvarez-Berastegui, A. Forcada, R. O, G. Criquet, S. Polti, G. Cadiou, C. Valle, P. Lenfant, P. Bonhomme, A. Perrez-Ruzafa, J. L. Sannchez-Lizaso, J. A. Garcia-Charton, G. Bernard, V. Stelzenmuller \& S. Planes, 2008. Spillover from six western Mediterranean marine protected areas: evidence from artisanal fisheries. Marine Ecology Progress Sereries 366:159174 doi:10.3354/meps07532.

Groeneveld, J. C., 2002. Long-distance migration of the rock lobster Palinurus delagoae off South Africa and Mozambique. South African Journal of Marine Science 24:395-400.

Groeneveld, J. C. \& G. M. Branch, 2002. Long-distance migration of South African deep-water rock lobster Palinurus gilchristi. Marine Ecology Progress Sereries 232:225-238 doi:10.3354/meps232225.

Guerra-Castro, E., C. Carmona-Suárez \& J. Conde, 2011. Biotelemetry of crustacean decapods: sampling design, statistical analysis, and interpretation of data. Hydrobiologia 678(1):1-15 doi:10.1007/s10750-011-0828-8.

Guerao, G., K. B. Andree, C. Froglia, C. G. Simeo \& G. Rotllant, 2011. Identification of European species of Maja (Decapoda: Brachyura: Majidae): RFLP analyses of COI mtDNA and morphological considerations. Scientia Marina 75(1):129134 doi:10.3989/scimar.2011.75n1129.

Guerao, G., E. Pastor, J. Martin, M. Andres, A. Estevez, A. Grau, J. Duran \& G. Rotllant, 2008. The larval development of Maja squinado and M. brachydactyla (Decapoda, Brachyura, Majidae) described from plankton collected and laboratory-reared material. Journal of Natural History 42(33-34):2257-2276 doi:10.1080/00222930802254755. 
515 Guerao, G. \& G. Rotllant, 2010. Development and growth of the early juveniles of the spider crab Maja squinado (Brachyura: Majoidea) in an individual culture system. Aquaculture 307(1-2):105-110 doi:10.1016/j.aquaculture.2010.06.006.

Herrnkind, W. F., 1980. Spiny lobsters: patterns of movement. In Cobb, J. S. \& B. F. Phillip (eds) The Biology and Management of Lobsters, vol. 1. Physiology and

Hyland, S. J., B. J. Hill \& C. P. Lee, 1984. Movement within and between different Hunter, E., 1999. Biology of the European spiny lobster, Palinurus elephas (Fabricius, 1787) (Decapoda, Palinuridea). Crustaceana 72:545-565 doi:10.1163/156854099503609.

Hines, A. H., T. G. Wolcott, E. Gonzalez-Gurriaran, J. L. Gonzalez-Escalante \& J. Freire, 1995. Movement patterns and migrations in crabs - telemetry of juvenile and adult behavior in Callinectes sapidus and Maja squinado. Journal of the Marine Biological Association of the United Kingdom 75(1):27-42.

Hill, B. J., 1975. Abundance, breeding and growth of the crab Scylla serrata in two South African estuaries. Marine Biology 32(2):119-126 doi:10.1007/BF00388505. 
Johnson, E. G., A. C. Young, A. H. Hines, M. A. Kramer, M. Bademan, M. R. Goodison \& R. Aguilar, 2011. Field comparison of survival and growth of hatchery-reared versus wild blue crabs, Callinectes sapidus Rathbun. Journal of Experimental Marine Biology and Ecology 402(1-2):35-42 doi:10.1016/j.jembe.2011.03.013.

Jernakoff, P. \& B. F. Phillipis, 1988. Effect of a baited trap on the foraging movements of juvenile western rock lobsters, Panulirus cygnus George. Australian Journal of Marine and Freshwater Research 39:185-192.

Kelly, S., 2001. Temporal variation in the movement of the spiny lobster Jasus edwardsii. Marine and Freshwater Research 52(3):323-331 doi:10.1071/mf00028.

Latrouite, D., Y. Desaunay, H. De Pontual, H. Troadec, P. Lorance, F. Galgani, P. Bordalo Machado, G. Bavouzet, P. Noel, G. Veron, P. Danel \& O. Dugornay, 1999. Compte-rendu de la campagne OBSERVHAL98 - Observations à finalité halieutique. 200 pp.

Latrouite, D. \& D. Le Foll, 1989. Donnees sur les migrations des crabes tourteau Cancer pagurus et les araignees de mer Maia squinado. Oceanis 15:133-142.

Le Foll, D., 1993. Biologie et exploitation de l'araignee de mer Maja squinado Herbest en Manche ouest Rapport Interne de la Direction des ressources Vivantes. Vol 93.030. IFREMER, Brest, 517.

Le Vay, L., V. N. Ut \& M. Walton, 2007. Population ecology of the mud crab Scylla paramamosain (Estampador) in an estuarine mangrove system; a mark-recapture study. Marine Biology 151(3):1127-1135 doi:10.1007/s00227-006-0553-4. 
Le Vay, L., M.J.H. Lebata, M. Walton, J. Primavera, E. Quinitio, C. Lavilla-Pitogo, F. Parado-Estepa, E. Rodriguez, V.N. Ut, T.T .Nghia, P. Sorgeloos, M. Wille, 2008. Approaches to Stock Enhancement in Mangrove-Associated Crab Fisheries. Reviews in Fisheries Science, 16(1-3):72-80.

Lebata, M., L. Le Vay, M. E. Walton, J. B. Binas, E. T. Quinitio, E. M. Rodriguez \& J. H. Primavera, 2009. Evaluation of hatchery-based enhancement of the mud crab, Scylla spp., fisheries in mangroves: comparison of species and release strategies. Marine and Freshwater Research 60(1):58-69 doi:10.1071/mf08155.

Linnane, A., W. Dimmlich \& T. Ward, 2005. Movement patterns of the southern rock lobster, Jasus edwardsii, off South Australia. New Zeland Journal of Marine and Freshwater Research 39:335-346.

MacArthur, L.D., R.C. Babcock \& G.A. Hyndes, 2008. Movements of the western rock lobster (Panulirus cygnus) within shallow coastal waters using acoustic telemetry. Marine and Freshwater Research, 59, 603-613.

MacDiarmid, A. B., 1991. Seasonal changes in depth distribution, sex ratio and size frequency of spiny lobster Jasus edwardsii on a coastal reef in northern New Zealand. Marine Ecology Progress Series 70:129-141.

McGarvey, R. 2004. Estimating the emigration rate of fish stocks from marine sanctuaries using tag-recovery data. Fishery Bulletin 102(3): 464-472.

Nonaka, M., H. Fushimi \& T. Yamakawa, 2000. The spiny lobster fishery on Japan and stocking. In Phillips, B. F. \& J. Kittaka (eds) Spiny lobsters: fisheries and culture. 2nd edition edn. Fishing News Books (Blackwell), Oxford, UK, 221242. 
Okamoto, K., 2004. Juvenile release and market size recapture of the swimming crab Portunus trituberculatus (Miers) marked with coded wire tags. In K. M. Leber, S. K., H. L. Blankenship and T. Svasand (ed) Stock Enhancement and Sea Ranching: Developments, Pitfalls and Opportunities. Blackwell Publishing Ltd., Oxford, 181-186.

Revenga, S., F. Fernández, J. L. González \& E. Santaella, 2000. Artificial reefs in spain:the regulatory framework. In Jensen, A. C., K. J. Collins \& A. P. M. Lockwood (eds) Artificial reefs in European seas. Kluwer Academic Publishers, Dordretch, The Netherlands, 185-194.

Rotllant, G., G. Guerao, N. Gras \& A. Estevez, 2014. Growth and biochemical composition during larval and molting stages of the spider crab, Maja squinado (decapoda: majidae). Aquatic Biology 20:13-21.

Sardà, F. \& P. Martin, 1986. Les pesqueries a Catalunya: evolució en els últims quatre decenis. In Demestre, M., J. Lleonart, P. Martin, J. A. Peitx \& F. Sardà (eds) L'oceanografia Recursos pesquers de la mar catalana. vol 9. Diputació de Barcelona, Barcelona, Spain, 91-112.

Sotelo, G., P. Morán \& D. Posada, 2009. Molecular phylogeny and biogeographic history of the European Maja spider crabs (Decapoda, Majidae). Molecular Phylogenetics and Evololution 53:314-319.

Spanier, E., M. Tom, S. Pisanty \& G. Almog, 1988. Seasonality and shelter selection by the slipper lobster Scyllarides latus in the south-eastern Mediterranean. Marine Ecology Progress Series 42:247-255.

Stevcic, Z., 1967. A short outline ofthe biology ofthe spinous spider crab. Bull Sci Cons Acad RSF Yugosl Sect A 12:313-314. 
611 Stevcic, Z., 1968. Relations interspécifiques de l'araignée de mer. Rapport de Commitée internationale de Mer Méditerranée 19(2):147-149.

613 Stevcic, Z., 1973. Les migrations de l' Araignée de mer. Rapports de la Commision 614 International de la Mer Méditerranée 21:597-598.

615 Stevcic, Z., 1977. [Contribution to the knowledge of the reproduction of the spider crab 616 (Maja squinado)]. Rapp P-V Reun, Comm Int Explor Sci Mer Mediterr, Monaco, 24(4), 177-178.

618 Ungfors, A., H. Hallback \& P. G. Nilsson, 2007. Movement of adult edible crab (Cancer pagurus L.) at the Swedish West Coast by mark-recapture and acoustic

620 tracking. Fisheries Research 84(3):345-357 doi:10.1016/j.fishres.2006.11.031. hatchery-reared and wild Scylla paramamosain (Estampador, 1949) in pond culture. Aquac Res 38(14):1593-1599 doi:10.1111/j.1365-2109.2007.01744.x. 


\section{Figure Captions}

626 Fig. 1 Map showing the location of the coastal Seafloor Observatory (OBSEA), where the 627 artificial reefs (AR) are situated.

628 Fig. 2 Schematic representation of the artificial reefs (AR) close to the coastal Seafloor 629 Observatory (OBSEA). VEMCO Ltd VR2W Coded Acoustic Hydrophones (H1, H2 630 and H3) were situated in the middle of each reef module and a fourth one (H4) in the 631 geographic centre among the three AR where the other $\mathrm{H}$ were located.

632 Fig. 3 Movement ranges of spiny lobsters Palinurus mauritanicus (a) and spider crabs 633 Maja squinado (b) in the reception area of the hydrophones located in the artificial reefs. P: 634 spiny lobster; M: spider crab. 


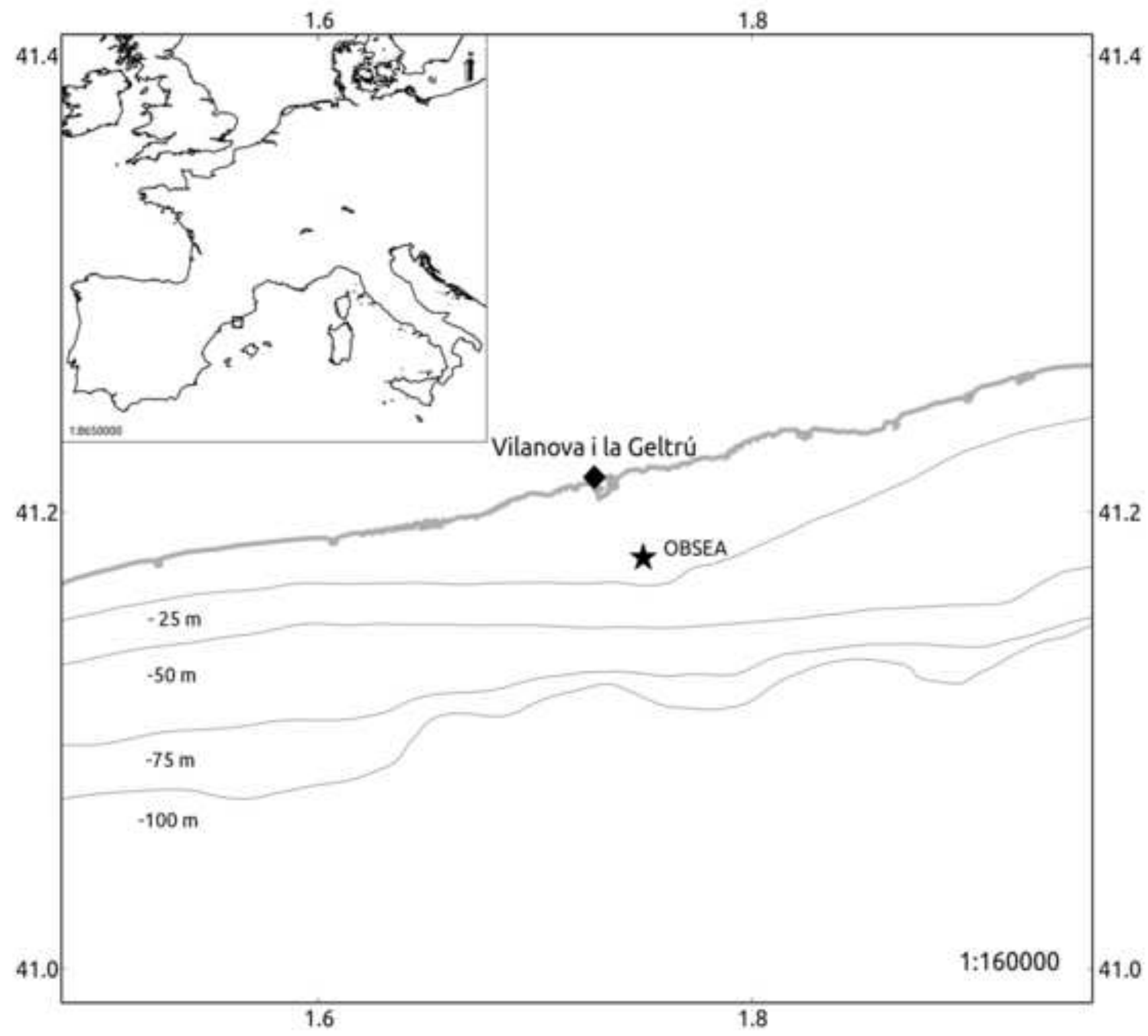




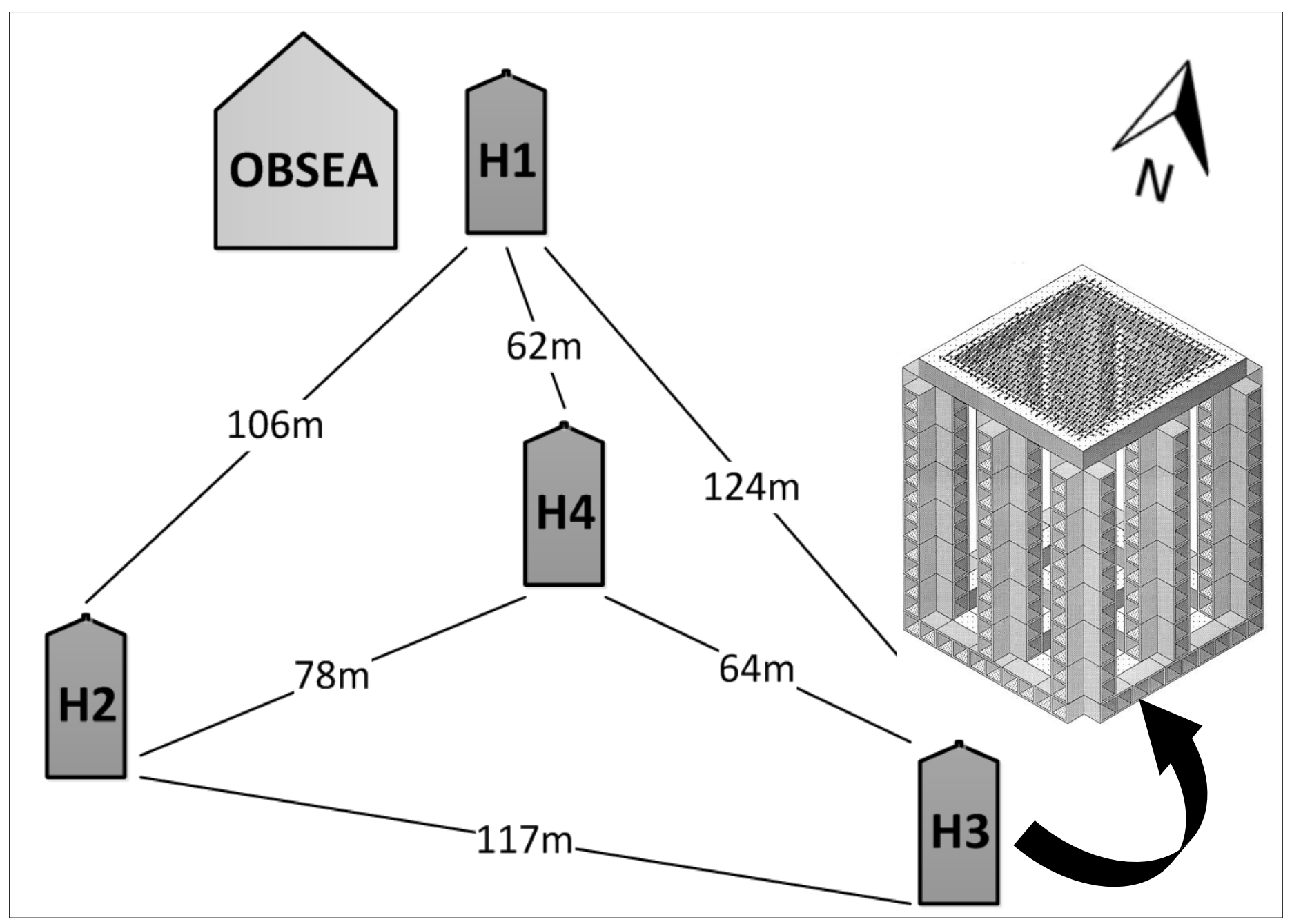


A)

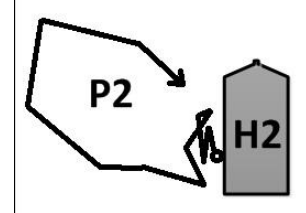

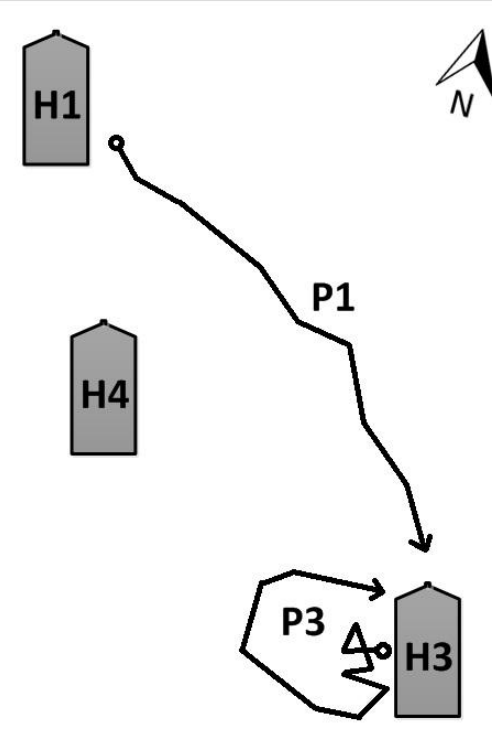

B)

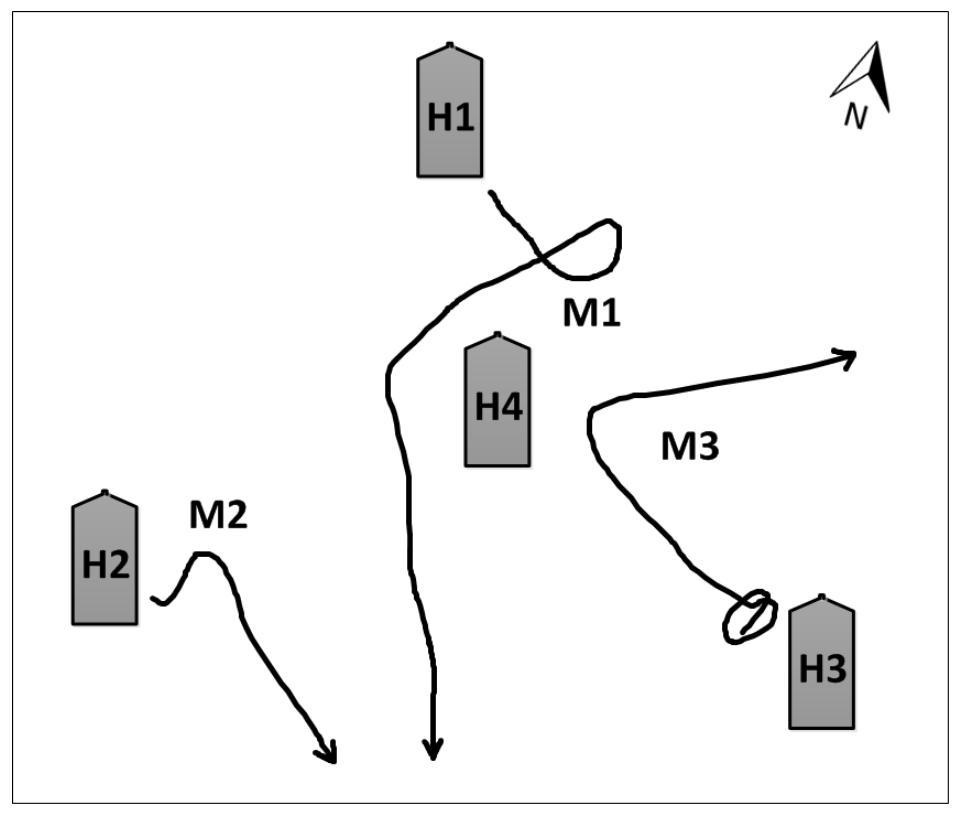


Table 1. Identification of transmetters and durantion of the reception of the sound per species.

\begin{tabular}{|l|c|c|c|c|c|c|c|}
\hline Species & $\begin{array}{c}\text { No. } \\
\text { Transmitter }\end{array}$ & $\begin{array}{c}\text { Animal } \\
\text { code }\end{array}$ & $\begin{array}{c}\text { Artificial reef } \\
\text { of release }\end{array}$ & $\begin{array}{c}\text { Sound } \\
\text { reception } \\
\text { (days) }\end{array}$ & $\begin{array}{c}\text { Total } \\
\text { movement } \\
(\mathrm{m})\end{array}$ & $\begin{array}{c}\text { Mean rate of } \\
\text { movement } \\
\left(\mathrm{m} \mathrm{d}^{-1}\right)\end{array}$ & Track spot points \\
\hline \multirow{2}{*}{$\begin{array}{l}\text { Palinurus } \\
\text { maritanicus }\end{array}$} & 772 & $\mathrm{P} 1$ & AR1 & 41 & 114 & 2.78 & 148680 \\
\cline { 2 - 8 } & 771 & P2 & AR2 & $10+20^{*}$ & $80^{* *}$ & 2.67 & 60856 \\
\cline { 2 - 8 } & 770 & P3 & AR3 & 10 & $40^{\star *}$ & 4 & 14028 \\
\hline \multirow{3}{*}{ Maja squinado } & 767 & M1 & AR1 & 21 & 140 & 160 & 1858 \\
\cline { 2 - 8 } & 768 & M2 & AR2 & 45 & 90 & 48 & 243 \\
\cline { 2 - 8 } & 764 & M3 & AR3 & 26 & 118 & 108.92 & 3395 \\
\hline
\end{tabular}

No clear signal received between 28/7/2011 and 31/8/2011

** Imprecise due no clear signal between hydrophones 
Table 2. Probability $(\mathrm{P}<0.001)$ between movement of the crustaceans and environmental parameters.

\begin{tabular}{|l|c|r|r|r|r|r|r|}
\hline Species & $\begin{array}{c}\text { Animal } \\
\text { code }\end{array}$ & $\begin{array}{c}\text { Temperature } \\
\left({ }^{\circ} \mathrm{C}\right)\end{array}$ & $\begin{array}{c}\text { Pressure } \\
(\mathrm{dBar})\end{array}$ & $\begin{array}{c}\text { Salinity } \\
(\mathrm{PSU})\end{array}$ & $\begin{array}{c}\text { Current } \\
\text { Speed }\left(\mathrm{m} \mathrm{s}^{-1}\right)\end{array}$ & $\begin{array}{c}\text { Current } \\
\text { direction } \\
(\mathrm{degrees})\end{array}$ & $\begin{array}{c}\text { Light Intensity } \\
\left(\mathrm{W} \mathrm{m}^{-2}\right)\end{array}$ \\
\hline Palinurus maritanicus & P1 & $-0,1045$ & $-0,21959^{*}$ & $-0,061604$ & $-0,15251$ & $-0,097988$ & 0,13373 \\
\hline & P2 & 0,1791 & $0,24529^{*}$ & $0,29209^{*}$ & 0,16844 & $-0,031496$ & $-0,040897$ \\
\hline & P3 & $-0,25282^{*}$ & $-0,02879$ & $-0,21139^{*}$ & 0,099221 & 0,14371 \\
\hline Maja squinado & M1 & $0,3096^{*}$ & $-0,15889$ & $0,50736^{*}$ & 0,16683 & $-0,01431$ \\
\hline & M2 & $0,29567^{*}$ & $-0,1548$ & 0,15732 & 0,050236 & $0,25071^{*}$ & $0,42594^{*}$ \\
\hline & M3 & $0,26404^{*}$ & $-0,39998^{*}$ & 0,075104 & $0,29035^{*}$ & $-0,1535$ \\
\hline
\end{tabular}

*Significant differences. 

attachment to manuscript
Click here to download att

Click here to download attachment to manuscript: Letter to editors Response to reviewers- Marcatge-27-1-2014_sent.docx

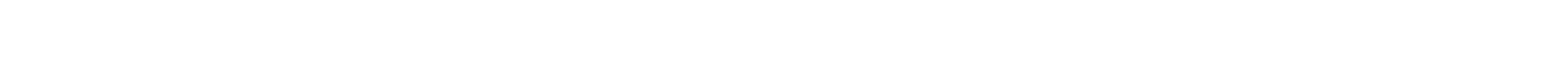
西 (1) 西 . . . . . . . . . . . . 西 西 西 西 (1) (1) . . . . . . (1) 